\section{BUOY AS A TOOL IN TEACHING BASIC ELEMENTS OF SAILING}

\section{PLUTAČA KAO POMAGALO U PODUCI OSNOVNIH ELEMENATA JEDRENJA}

\section{Nikola Prlenda ${ }^{1}$, Ivan Oreb $^{1} \&$ Danijela Vujčić ${ }^{1}$}

${ }^{1}$ Faculty of Kinesiology University of
Zagreb, Zagreb, Croatia

Original scientific paper doi:10.5550/sgia.181401.en.pov UDC: 797.14

\section{SUMMARY}

The aim of the research is to determine efficiency of buoys as a methodic tool in teaching and learning of basic elements of sailing. Analyzed sailing elements were heading up, tacking, bearing away and jibing on three different sailing positions (helm, main sail and jib). The research was carried out on the sample of 178 Kinesiology faculty students, divided into two groups (control group and experimental group). The experimental group examinees were subjected to teaching using various buoy ranges, while control group examinees were subjected to classic teaching methods (without buoy range). The teaching process was carried out during seven days period on Elan 19 sailboats. Teaching and evaluation of sailing elements was conducted by teachers with long experience in teaching of sailing. By means of descriptive statistics the difference in amount of acquired knowledge using two different models of teaching of sailing skills was determined. The results of descriptive statistics show higher score for examinees of experimental group in almost all elements of sailing technique, except in element tacking-jib. One-way analysis of variance showed that those differences are significant on the position helmsman in elements heading up, bearing away and jibbing, on the position mainsail, in the element heading up and also on the jib position, element heading up. Through further analysis, a discriminant analysis confirmed significant difference in the amount of acquired knowledge of sailing technique between two analyzed groups $\left(\chi^{2}=47,73, p=0,00\right)$. Finally, the authors conclude that buoy range had significant influence on the amount of acquired knowledge of sailing skills.

Key words: buoy range, teaching methods, sailor, sailing school, beginner 


\section{INTRODUCTION}

In the last two decades interest in sailing and its popularity are constantly increasing (Neville \& Folland, 2009; Having et al, 2013), resulting today in the existence of hundreds of sailing classes (Allen \& De Jong, 2006), and in over 16 million people enjoying sailing (Neville \& Folland, 2009) in both recreational and competitional way. Constant development of nautical tourism in the world, opening of numerous sailing schools, and organizing of more and more big sailing competitions demand professional staff in sailing ever growing in number and quality. Furthermore, increasing tempo of life is causing that guests stay for a shorter period of time, so it is necessary to adjust sailing school programs to their needs as well. These are exactly the reasons why it is expected of buoy range to speed up, and with it to improve the quality of teaching. Today, buoy range is everyday tool in teaching of recreationalists, competitors, children etc. Oreb (2000) speaks of „buoy corridor“ as a tool that, from the organizational aspect, enables extraordinary control of a sailor, spatial definition and awareness, sureness in moving himself and moving among other sailboats. Also, from the methodic aspect, buoys are represented as a landmark by means of which sailor is able to comprehend, experience and carry out elements such as heading up, tacking, bearing away and jibing. Besides, Oreb concludes that such ranges are satisfying considering game playing, situational behavior and technique mastering. White \& Wells (1995) bring a series of examples of ranges as possible means in teaching of competitors. When speaking about buoy range, it is not hard to recognize many advantages that such kind of tool, or playground, brings into teaching of sailing skills. Nevertheless, in praxis some issues arise questioning actual profitability of buoy range. In that matter, there is an obvious problem of time necessary to install such a range, especially in areas where the depth of the sea is often up to 150 meters. These were the problems that induced the authors to carry out the research in order to find out when and to which extent exactly do buoy ranges contribute to acquiring of sailing skills.

\section{METHODS}

The research was conducted on the sample of 178 Kinesiology faculty students, that were divided into control $(n=86)$ and experimental $(n=92)$ group by random selection. The main condition examinees should fulfill to enter examinee specimen is that they have never been sailing. To determine the level of acquired mastering of sailing skills, four main

Prlenda, N., Oreb, I., \& Vujčić, D. (2018). Buoy as a tool in teaching basic elements of sailing. Sportlogia, 14 (1), 47-58. doi: 10.5550/sgia.181401.en.pov 
technique elements were selected (heading up, tacking, bearing away and jibing) on three working positions (helm, main sail, jib) on the Elan 19 sailboat.

Elements were evaluated on the basis of video footage used to document demonstration of mentioned elements by examinees. The evaluation of learned specific motor knowledge in sailing domain was carried out by three educated reviewers with long experience in sailing skills evaluation. The reviewers were instructed beforehand on criteria of assessing of every element. All reviewers made their evaluation simultaneously and independently. Sailing knowledge in this research was evaluated through scores ranging from 1-5, and the results of evaluation were expressed through five-point Likert scale, which ranks as ordinal measurement scale (Mejovšek, 2003 according to Supek, 1981). Elements learned by the examinees are part of the every sailing school training in the world, and are taught as a part of the regular curriculum in the Kinesiology faculty of the University in Zagreb. With the aim of conducting of planned research, an experiment was carried out in duration of four weeks, while the process of teaching individual student lasted for seven days (Table 1). Examinees of experimental group were subjected to teaching by means of different buoy ranges, while examinees of control group were submitted to classical teaching methods (without buoy range). Very important factor in the research conduction was choosing of examinees with the same sailing experience, and also ensuring the equal conditions during the training. The training and knowledge evaluation of all the examinees took place on the same type of sailboat (Elan 19), in the same waters. All examinees had optimal wind conditions (between 4 and 6 knots), and calm to slightly rough sea.

Table 1 Sailing technique elements teaching and training plan

\begin{tabular}{|c|c|c|}
\hline \multirow{2}{*}{$\begin{array}{c}\text { Teaching } \\
\text { course }\end{array}$} & \multicolumn{2}{|c|}{ Distribution of sailing technique elements by days } \\
\cline { 2 - 3 } & Experimental group & Control group \\
\hline 1 st day & $\begin{array}{c}\text { Basic information on the sailboat and the } \\
\text { equipment }\end{array}$ & $\begin{array}{c}\text { Basic information on the sailboat and } \\
\text { the equipment }\end{array}$ \\
\cline { 2 - 3 } & \begin{tabular}{c} 
Sailing positions and moving on the boat \\
\cline { 2 - 3 }
\end{tabular} & $\begin{array}{c}\text { Sailing positions and moving on the } \\
\text { boat }\end{array}$ \\
\cline { 2 - 3 } & Sail raising & Sail raising \\
\hline 2nd day & Sail adjusting & Crosswind sailing \\
\hline
\end{tabular}

Prlenda, N., Oreb, I., \& Vujčić, D. (2018). Buoy as a tool in teaching basic elements of sailing. Sportlogia, 14 (1), 47-58. doi: 10.5550/sgia.181401.en.pov 


\begin{tabular}{|c|c|c|}
\hline & Crosswind sailing in buoy range & Sail adjusting \\
\hline \multirow[t]{3}{*}{ 3rd day } & Heading up & \multirow{2}{*}{ Heading up } \\
\hline & \multirow[b]{2}{*}{$\begin{array}{c}\text { Heading up and bearing away in buoy } \\
\text { range }\end{array}$} & \\
\hline & & Bearing away \\
\hline \multirow[t]{3}{*}{ 4th day } & Maximum heading up & \multirow{2}{*}{ Maximum heading up } \\
\hline & Maximum bearing away & \\
\hline & $\begin{array}{l}\text { Maximum heading up and bearing away } \\
\text { in buoy range }\end{array}$ & Maximum bearing away \\
\hline \multirow[t]{2}{*}{ 5th day } & Tacking & \multirow[t]{2}{*}{ Tacking } \\
\hline & Tacking in buoy range & \\
\hline \multirow[t]{2}{*}{ 6th day } & Jibing & \multirow[t]{2}{*}{ Jibing } \\
\hline & Jibing in buoy range & \\
\hline \multirow[t]{2}{*}{7 th day } & Repetition & Repetition \\
\hline & Assessment & Assessment \\
\hline
\end{tabular}

All the data obtained were processed by statistic package for data processing „Statistica 8“. For every group (experimental and control) basic statistical elements were calculated individually: arithmetic mean and standard deviation. By means of discriminant analysis the existence of significant difference was determined between experimental and control group when applying different methodic procedures in teaching and training of sailing technique elements. Also, aplying one-way analysis of variance (Anova) significant difference was determined between experimental and control group for every criterion variable individually.

\section{RESULTS}

As described before, three reviewers were assessing the amount of knowledge acquired by students on twelve sailing technique elements. Their objectivity was determined through correlation between given scores on individual technique element (from $r=64$ to $\mathrm{r}=94$ ), and using factor analysis it was determined that their object of assessment is highly 
concordant meaning that they observe and assess the same thing, enabling applying of the mean score by three reviewers for the individual technique element in the further research.

In Table 2 the results of descriptive statistics are shown (arithmetic mean and standard deviation) for both groups of examinees and also results of one-way analysis of variance.

Table 2 Descriptive indicators for both examinee group and results of one-way analysis of variance

\begin{tabular}{|c|c|c|c|c|c|c|}
\hline \multirow[t]{2}{*}{ Sailing elements } & \multicolumn{2}{|c|}{$\begin{array}{c}\text { Experimental } \\
\text { group } \\
\text { (buoy range) }\end{array}$} & \multicolumn{2}{|c|}{$\begin{array}{l}\text { Control } \\
\text { group }\end{array}$} & \multicolumn{2}{|c|}{ ANOVA } \\
\hline & M & SD & M & SD & $\mathrm{F}$ & $\mathrm{p}$ \\
\hline Heading up-helm $(\mathrm{HH})$ & 3,77 & 0,79 & 3,40 & 0,70 & 10,61 & $\mathbf{0 , 0 0}$ \\
\hline $\begin{array}{l}\text { Heading up-mainsail } \\
\text { (HM) }\end{array}$ & 3,87 & 0,72 & 3,48 & 0,61 & 14,89 & $\mathbf{0 , 0 0}$ \\
\hline Heading up-jib (HJ) & 3,69 & 0,67 & 3,46 & 0,72 & 5,07 & $\mathbf{0 , 0 3}$ \\
\hline Tacking- helm (TH) & 3,59 & 0,76 & 3,39 & 0,87 & 2,65 & 0,11 \\
\hline $\begin{array}{l}\text { Tacking - mainsail } \\
\text { (TM) }\end{array}$ & 3,73 & 0,73 & 3,63 & 0,71 & 0,87 & 0,35 \\
\hline Tacking - jib (TJ) & 3,57 & 0,77 & 3,63 & 0,74 & 0,27 & 0,60 \\
\hline $\begin{array}{l}\text { Bearing away- helm } \\
\text { (BH) }\end{array}$ & 3,67 & 0,69 & 3,39 & 0,67 & 7,65 & $\mathbf{0 , 0 1}$ \\
\hline $\begin{array}{l}\text { Bearing away - } \\
\text { mainsail (BM) }\end{array}$ & 3,74 & 0,69 & 3,61 & 0,71 & 1,44 & 0,23 \\
\hline Bearing away - jib (BJ) & 3,60 & 0,64 & 3,50 & 0,68 & 1,15 & 0,28 \\
\hline Jibing- helm (JH) & 3,65 & 0,75 & 3,31 & 0,77 & 8,94 & $\mathbf{0 , 0 0}$ \\
\hline Jibing - mainsail (JM) & 3,66 & 0,80 & 3,50 & 0,66 & 2,29 & 0,13 \\
\hline Jibing - jib (JJ) & 3,58 & 0,65 & 3,57 & 0,70 & 0,02 & 0,89 \\
\hline
\end{tabular}

It is evident that arithmetic means of scores for examinees are higher for experimental group examinees in all elements of sailing technique except in element tacking-jib. In experimental group the lowest scores were achieved in elements tacking and jibing on jib position $(3,57$ and 3,58), and highest mean scores were achieved on element heading up, on main sail and helm position $(3.87,3.77)$, while situation was reversed for control group, meaning that the lowest scores were given on helm position for every sailing element (JH3,31, BH-3,39, TH-3,39, HH-3,40,) and higher average scores were achieved on jib and mainsail position (TM-3,63 and TJ-3.63).

The biggest differences in arithmetic means were for elements heading up- main sail (0.39), heading up - helm (0.37) and jibing - helm $(0,34)$, while differences are the smallest in jibing - jib(0.01), tacking - jib (-0. 06) and bearing away - jib (0. 10).

Prlenda, N., Oreb, I., \& Vujčić, D. (2018). Buoy as a tool in teaching basic elements of sailing. Sportlogia, 14 (1), 47-58. doi: 10.5550/sgia.181401.en.pov 
Results of one-way analysis of variance show the existence of significant difference in models applied, on the helmsman position for elements heading up, bearing away and jibing, on main sail position for element heading up, and on jib position for element heading up in favor of experimental group.

By means of discriminant analysis the significance in difference is determined for sailing technique performance between experimental and control group. It is shown by significance level of the $\chi^{2}$ test (p) which is lower than 0,01 (Table 3).

Table 3 Results of discriminant function between experimental and control group

\begin{tabular}{|cccccc|}
\hline$\lambda$ & $\mathrm{Rc}$ & $\mathrm{w} \lambda$ & $\chi^{2}$ & $\mathrm{df}$ & $\mathrm{p}$ \\
\hline 0,32 & 0,49 & 0,76 & 47,73 & 12 & 0,00 \\
\hline
\end{tabular}

$\lambda$ - eigenvalue, Rc - canonical correlation, $\mathrm{w} \lambda$ - Wilks' lambda, $\chi^{2-}$ values of chi-square test, $\mathrm{df}$ - number of degrees of freedom, $\mathrm{p}$ - significance level of discriminant function

In Table 4 correlations of variables to discriminant function is shown, while in Table 5 location of centroids for experimental and control group on discriminant function are displayed.

Table 4 Correlation of variables to discriminant function

\begin{tabular}{|c|c|}
\hline Variables & \\
\hline Heading up-main sail & 0,51 \\
Heading up-helm & 0,43 \\
Jibing-helm & 0,40 \\
Bearing away-helm & 0,37 \\
Heading up-jib & 0,30 \\
Tacking-helm & 0,22 \\
Jibing-main sail & 0,20 \\
Bearing away-main sail & 0,16 \\
Bearing away-jib & 0,14 \\
Tacking-main sail & 0,12 \\
Tacking-jib & $-0,07$ \\
Jibing-jib & 0,02 \\
\hline
\end{tabular}

Prlenda, N., Oreb, I., \& Vujčić, D. (2018). Buoy as a tool in teaching basic elements of sailing. Sportlogia, 14 (1), 47-58. doi: 10.5550/sgia.181401.en.pov 
Table 5 Location of centroids of groups on the discriminant function

\begin{tabular}{|cc|}
\hline $\begin{array}{c}\text { Location of centroids of } \\
\text { experimental(1) and } \\
\text { control group(2) }\end{array}$ \\
\hline 1 & 0,55 \\
2 & $-0,59$ \\
\hline
\end{tabular}

Examinees of control group are positioned on negative pole of discriminant function and have value of $-0,59$, while average score of experimental group is on positive pole $(0$, 55). The structure of discriminant function is also bipolar. According to correlations of variables to discriminant function, it is evident that examinees of experimental group achieve better results in all the elements of sailing technique, except on variable tacking - jib $(-0,07)$ where control group examinees have slightly better average result. The most significant projection on discriminant function has variable heading up - mainsail $(0,51)$, then follows heading up - helm $(0,43)$, jibing - helm $(0,40)$, bearing away - helm $(0,37)$ and heading up jib $(0,3)$ while other variables have correlation to discriminant function lower than 0,3 .

\section{DISCUSSION}

The biggest problem for basic sailing school attendants is spatial disorientation, mostly increased by undeveloped sense for wind direction. It is known that wind cannot be seen, but must be sensed, and this problem is bigger when the wind is weak (Pluijms et al, 2015), as is the case with our examinees and most beginners.

Wheras in sailing, conditions are different on every sailing position (Allen \& de Jong, 2006), it is to be expected that some students will cope better with some position than the other. Years of practice show that beginners have bigger problems in adjustment to helm position than to main sail or jib position, which is a logical result of aforementioned bad orientation, since helmsman is exactly the person directing the boat and having he biggest responsibility, while sailors on main sail and jib are following him and are adjusting sails to his direction of sailing. The same reason makes an element as heading up difficult for beginners, because it is necessary to determine the point to which sailing up wind is possible. Also, it is proven that in every competitive sailing course, two thirds of total racing time is spent on sailing upwind (Callewaert et al, 2014), it is not much different in teaching of sailing, which makes it difficult to concentrate, especially for beginners. 
It is interesting to notice that results achieved in control group show expected difficulty for sailboat positions (helm, main sail, jib). These results are especially interesting when compared to the experimental group, in which examinees were subjected to teaching using buoy range, and the ratio of average scores was completely changed, showing highest results for element heading up on main sail and helm position (Table 1). So, the biggest differences in arithmetic means between the two groups are for elements heading up - main sail (0.39), heading up - helm (0.37) and jibing - helm (0,34).

Univariate analysis of variance confirmed that differences between the two groups for these three variables are significant at significance level $p=0,05$, and also showed that the two groups are significantly different for variables tacking - helm and heading up - jib.

By means of discriminant analysis significant difference was determined (significance level of $\chi^{2}$ test lower than 0,01 ) for the sailing technique performance between control and experimental group (Table 2), in favor of experimental group which is positioned on the positive pole of discriminant function (Table 4). Correlations of variables to discriminant function (Table 3) confirmed the results of univariate analysis of variance and showed that five mentioned variables have the biggest projection on discriminant function and that these are exactly the ones making the greatest difference between the two groups of examinees.

Based on the results achieved we can conclude that experimental group is superior to the control group, especially on more demanding elements of sailing technique such as heading up, and on the more demanding helmsman position, therefore we are certain that we can claim these results to be the consequence of buoy range application. From the perceptual area, sailing is a sport that requires a high level of visual stimulus perception (Manzanares et al, 2015). The most important role of buoy range is its help in understanding of sailing space to beginner, and facilitating orientation to the wind (Oreb, 2000). Intelligence and attention underlie learning (Alexandru \& Gloria, 2015), using buoy range we help the beginner to pay attention better and we enable him to concentrate on basic maneuvers in directing the boat, or in adjusting the sails. The biggest problem for basic sailing school attendants, as we mentioned before, is spatial disorientation and we believe that it is the very problem evident in control group. Therefore we can conclude that buoy range has successfully lessened the confusion in heads of experimental group examinees which is result of loosing of spatial orientation, and is mainly evident in helmsman who is responsible for adjusting of angle of sailboat in relation to the wind. It is also possible to assume that using the buoy range increased the interest in examinees for training during the teaching. 
Results achieved through this research are difficult to compare to the existing knowledge. Namely, although in the last two decades number of scientific researches in sailing is significantly increased, (Felici et al.,1999), there are very few facts that are directing to the research revealing optimal methodical procedures and tools, and accelerating process of teaching and learning sailing skills. One of those rare researches was conducted by Oreb (1984), but in agnate sport, windsurfing, in which synthetic learning method has shown to be superior to analytic method. Almost thirty years after, in his doctoral dissertation Prlenda (2012) is researching effectiveness of different teaching models in windsurfing. His research is partially concordant to this one. Shortly, although in that research experimental group examinees using buoy range show higher average scores than control group examinees, those differences were not statistically significant. Author explains it by stating that in the first days, when student is making his first steps on the windsurf board, he can be more concentrated to the demand not to step out of corridor (range), than he is to the performance of assigned element, and in that case buoy range can become disturbing factor in some individuals, instead of help. He is also sure that significance of buoy range is increasing with the advancement of the student and that the full role of buoy range would be evident in the further course of instruction.

Although mentioned researches were conducted in the agnate sport, nevertheless, movement structures are completely different and it is not surprising that the results are not completely concordant. To conclude, achieved results are showing applicability of buoy range in teaching beginner helmsman, especially in more demanding technique elements such as heading up in sailing. Although some advancement is evident in other elements too, it is not big enough to be considered significant. Such results will facilitate future planning and programming, and in the end even organization of sailing schools, thus accelerating the teaching and instruction process. Further, installation of buoy ranges in the areas where longer period of time is needed, for example due to the depth, will be therefore carried out only for learning of more demanding elements (heading up, etc.).

\section{CONCLUSION}

The research was carried out on two groups of examinees (experimental and control group) on which two different methodic approaches in teaching of sailing skills were applied. One group (control) was subjected to standard approach to teaching without using buoy range as a teaching tool, while the other group (experimental) was taught entirely by applying 
assignments on buoy range. It is important to mention that to all the examinees this was first encounter with sailing. Considering all analyzed results, it is possible to conclude that buoy range as a methodic tool has significant influence on the amount of acquired knowledge of sailing skills. Also, based on the results achieved, we can conclude that buoy range mostly affects the speed of acquiring of the most demanding elements for a beginner such as heading up. It means that in beginning phases of sailing school such ranges can be omitted (due to the difficult conditions during installation of such ranges and with aim to reduce time loss) and installed only in days when more difficult elements are taught. It should be mentioned that both these groups trained in ideal conditions with wind constantly between 4 and 6 knots and sea, due to the islands surrounding it, was calm or slightly rough. Because of the mentioned reasons, a question arises, would these results that are in favor of model using buoy range be more evident in situation of open sea ( fear of unknown, waves etc.), or would stronger wind facilitate orientation and with it lessen the differences between the two groups.

\section{REFERENCES}

Alexandru, M.A., \& Gloria, R. B. (2015). Intelligence influence in beginner student learning of sailing. Journal of Physical Education and Sport, 15(1), 114-119. https://doi.org/10.7752/jpes.2015.01019

Allen, J. B., \& De Jong, M. R. (2006). Sailing and sports medicine: A literature review. Commentary. British Journal of Sports Medicine, 40(7), 587-593. https://doi.org/10.1136/bjsm.2002.001669

PMid:16547146 PMCid:PMC2653898

Bøymo-Having L.A, Grävare M.B., Silbernagel K.G. (2013). A prospective study on dinghy sailors training habits and injury incidence with a comparison between elite sailor and club sailor during a 12-month period. British Journal of Sports Medicine, 47(13), 826831.

https://doi.org/10.1136/bjsports-2012-091841 PMid:23673519

Callewaert, M., Boone, J., Celle, B., De Clercq, D. \& Bourgois, J.G. (2014). Cardiorespiratory and Muscular Responses to Simulated Upwind Sailing Exercise in Optimist Sailors. Pediatric Exercise Science, 26, 56-63. https://doi.org/10.2165/00007256-200939020-00003

Felici, F., Rodio, A., Madaffari, A., Ercolani, L., \& Marchetti, M. (1999). The cardiovascular work of competitive dinghy sailing. Journal of Sports Medicine and Physical Fitness, 39(4), 309-314. https://doi.org/10.1080/17461391.2014.963690

Manzanares, A., Menayo, R., Segado F., Salmeron, D. \& Cano, J.A. (2015). A probabilistic model for analysing the effect of performance levels on visual behaviour patterns of

Prlenda, N., Oreb, I., \& Vujčić, D. (2018). Buoy as a tool in teaching basic elements of sailing. Sportlogia, 14 (1), 47-58. doi: 10.5550/sgia.181401.en.pov 
young sailors in simulated navigation. European Journal of Sport Science, 15(3), 203212.

https://doi.org/10.1080/17461391.2014.963690

PMid:25296294

Mejovšek, M. (2003). Uvod u metode znanstvenog istraživanja. Jastrebarsko, RH: Naklada Slap.

Neville, V., \& Folland, J. P. (2009). The epidemiology and aetiology of injuries in sailing. Sports Medicine, 39(2), 129-145.

https://doi.org/10.2165/00007256-200939020-00003

PMid:19203134

Oreb, G. (1984). Efekti primjene analitičkog i sintetičkog pristupa u obučavanju jedrenja na dasci. Kineziologija, 16(2), 185-192.

Oreb, G. (2000). „Hodnik“ plutača - jedriličarska igraonica. In M. Andrijašević (Eds.), Zbornik radova Znanstveno - stručnog savjetovanja „Slobodno vrijeme i igra“, $u$ sklopu 9. Zagrebačkog sajma sporta i nautike, (pp. 138-141). Zagreb, RH: Fakultet za fizičku kulturu, Sveučilišta u Zagrebu.

Pluijms, J.P., Cañal-Bruland, R., Bergmann Tiest, W.M., Mulder, F.A. \& Savelsbergh, G.J.P. (2015). Expertise effects in cutaneous wind perception. Atten Percept Psychophys, 77, 2121-2133.

https://doi.org/10.3758/s13414-015-0893-6

PMid:25896122 PMCid:PMC4521093

Prlenda, N. (2012). Učinkovitost različitih modela poduke jedrenja na dasci. Doktorski rad. Kineziološki fakultet, Sveučilišta u Zagrebu.

White, R., \& Wells, M. (1995). Race training - Great Britain

Prlenda, N., Oreb, I., \& Vujčić, D. (2018). Buoy as a tool in teaching basic elements of sailing. Sportlogia, 14 (1), 47-58. doi: 10.5550/sgia.181401.en.pov 


\section{SAŽETAK}

Cilj istraživanja je utvrditi učinkovitost plutača kao metodičkog pomagala u poduci $i$ učenju osnovnih elemenata jedrenja. Analizirane elemente jedrenja činili su prihvaćanje, letanje, otpadanje $i$ kruženje na tri različite jedriličarske pozicije (kormilo, glavno jedro $i$ flok).

Istraživanje je provedeno na uzorku od 178 studenata Kineziološkog fakulteta koji su bili podijeljeni u dvije grupe (kontrolna i eksperimentalna). Ispitanici eksperimentalne grupe bili su podvrgnuti poduci uz pomoć različitih poligona plutača dok su ispitanici kontrolne grupe bili podvrgnuti klasičnoj poduci (bez primjene poligona plutača). Proces poučavanja proveden je u trajanju od 7 dana na jedrilicama tipa Elan 19. Poučavanje te vrednovanje jedriličarskih elemenata provele su osobe s dugogodišnjim iskustvom u poduci jedrenja. Deskriptivnom statistikom utvrđena je razlika u količini usvojenog znanja primjenom dvaju modela učenja jedriličarskih vještina. Rezultati ukazuju na više ocjene ispitanika kod eksperimentalne grupe gotovo u svim elementima jedriličarske tehnike osim kod elementa letanje-flok. Jednosmjerna analiza varijance pokazala je da su te razlike značajne na poziciji kormilar u elementima prihvaćanje, otpadanje i kruženje, poziciji glavno jedro, element prihvaćanje te poziciji flok također element prihvaćanje. U daljnjoj analizi diskriminacijska analiza potvrdila je značajnu razliku po količini usvojenog znanja jedriličarske tehnike između dviju analiziranih grupa $\left(\chi^{2}=47,73, p=0,00\right)$.

Na temelju dobivenih rezultata autori zaključuju da poligon plutača značajno utječe na količinu usvojenog znanja jedriličarskih vještina.

Ključne riječi: poligon plutača, metode poučavanja, jedriličar, škola jedrenja, početnik

Received: 19.04.2018.

Approved: 02.06.2018.

Correspondence:

Danijela Vujčić, prof., postgraduate doctoral student danijela.vujcic@kif.hr danijelakostanic@gmail.com

Prlenda, N., Oreb, I., \& Vujčić, D. (2018). Buoy as a tool in teaching basic elements of sailing. Sportlogia, 14 (1), 47-58. doi: 10.5550/sgia.181401.en.pov 